\title{
ECONOMIC IMPLICATIONS OF THE FLOOD NARRATIVE
}

David S. Tucker, Department of Business and Accounting, The College of Idaho, U.S.A.

Thomas W. DeBerry, College of Business, Freed-Hardeman University, U.S.A.

\author{
dx.doi.org/10.18374/JIBE-21-1.1
}

\begin{abstract}
Many cultural traditions have a flood narrative, but the Biblical narrative is most well known. Scarcity, division of labor, and the law of comparative advantage are all present in the postlapsarian, prediluvian world. Prosperity is achieved. However, violent relationships are contrary to the nature of God; therefore, God sent the Flood.
\end{abstract}

Keywords: Scarcity, flood, division of labor, comparative advantage 